\title{
Variovorax defluvii sp. nov., isolated from sewage
}

Correspondence
Chi-Yong Ahn
cyahn@kribb.re.kr
Hee-Mock Oh
heemock@kribb.re.kr

\section{Long Jin, ${ }^{1}$ Kwang Kyu Kim, ${ }^{2}$ Chi-Yong Ahn ${ }^{1}$ and Hee-Mock Oh ${ }^{1}$}

\author{
${ }^{1}$ Environmental Biotechnology Research Centre, Korea Research Institute of Bioscience \& \\ Biotechnology, 125 Gwahak-ro, Yuseong-gu, Daejeon 305-806, Republic of Korea \\ ${ }^{2}$ Korean Collection for Type Cultures, Biological Resource Centre, Korea Research Institute of \\ Bioscience \& Biotechnology, 125 Gwahak-ro, Yuseong-gu, Daejeon 305-806, Republic of Korea
}

Chlorophenols belong to a group of toxic xenobiotics that are resistant to microbial attack and are widely used in industry as wood preserves, resulting in accumulation of these compounds in soils. Among the proteobacteria, members of the genera Alcaligenes, Arthrobacter, Azotobacter, Burkholderia, Pseudomonas, Ralstonia and Rhodococcus have been reported to degrade chlorophenols (Apajalahti \& Salkinoja-Salonen, 1987; Häggblom, 1990, 1992; Li et al., 1991; Martin-Le Garrec et al., 2001). The genus Variovorax within the family Comamonadaceae was proposed by reclassification of Alcaligenes paradoxus as Variovorax paradoxus, the type species of the genus (Willems et al., 1991). At the time of writing, the genus comprised five recognized species, Variovorax paradoxus (Willems et al., 1991), V. dokdonensis (Yoon et al., 2006), $V$. soli (Kim et al., 2006), V. boronicumulans (Miwa et al., 2008) and V. ginsengisoli (Im et al., 2010).

Two strains, $2 \mathrm{C} 1-\mathrm{b}^{\mathrm{T}}$ and $2 \mathrm{C} 1-21$, were isolated from sewage flowing into River Geumho in South Korea, during screening for 2-chlorophenol-degrading bacteria. Sewage samples were initially stimulated with 100 p.p.m. 2-chlorophenol; the stimulated cultures were serially diluted in

The GenBank/EMBL/DDBJ accession numbers for the $16 \mathrm{~S}$ rRNA gene sequences of strains $2 \mathrm{C} 1-\mathrm{b}^{\top}$ and $2 \mathrm{C} 1-21$ are HQ385753 and HQ385754, respectively.

A supplementary table is available with the online version of this paper.
$0.85 \%$ saline solution. Aliquots of each serial dilution were spread on R2A agar (Difco) and incubated at $25^{\circ} \mathrm{C}$ for 7 days. Two yellow colonies, designated $2 \mathrm{C} 1-\mathrm{b}^{\mathrm{T}}$ and 2C1-21, were isolated. Both of the isolates were subcultivated on R2A agar at $30{ }^{\circ} \mathrm{C}$ for $48 \mathrm{~h}$. Based on phylogenetic, phenotypic and chemotaxonomic analysis, the two strains should be placed in the genus Variovorax. The strains were further investigated using a polyphasic approach.

For most experiments, all strains were cultivated on R2A agar or broth (Difco) at $30{ }^{\circ} \mathrm{C}$ for $48 \mathrm{~h}$. V. boronicumulans KCTC $22010^{\mathrm{T}}$, V. dokdonensis KCTC $12544^{\mathrm{T}}, V$. ginsengisoli KCTC $12583^{\mathrm{T}}, V$. paradoxus ATCC $17713^{\mathrm{T}}$ and $V$. soli KACC $11579^{\mathrm{T}}$ were used as reference strains under the same conditions.

The Gram reaction was performed with $2 \%(\mathrm{w} / \mathrm{v})$ crystal violet, iodine fixation and decolorization. Decolorization was accomplished using $95 \%$ ethanol followed by a distilled water wash and counterstaining with safranin (Gerhardt et al., 1994). Cell morphology and motility were observed under a phase-contrast microscope (Nikon Optiphot; $1000 \times$ magnification) with cells grown on R2A agar for 1-3 days. Oxidase activity was tested using $1 \%$ tetramethyl-p-phenylenediamine (Tarrand \& Gröschel, 1982) and catalase activity was tested using $3 \% \mathrm{H}_{2} \mathrm{O}_{2}$. Growth was investigated on $\mathrm{R} 2 \mathrm{~A}$ agar at different temperatures $(4,8,10,15,20,25,30,32,37$, 42 and $\left.45{ }^{\circ} \mathrm{C}\right), \mathrm{NaCl}$ concentrations $(1,2,3$ and $5 \%)$ and 
pH 5-10 (at intervals of $1 \mathrm{pH}$ unit). Different $\mathrm{pH}$ values were achieved using appropriate biological buffers: $\mathrm{Na}_{2} \mathrm{HPO}_{4} /$ $\mathrm{NaH}_{2} \mathrm{PO}_{4}$ buffer and $\mathrm{Na}_{2} \mathrm{CO}_{3} / \mathrm{NaHCO}_{3}$ buffer were used for $\mathrm{pH}$ values of 5-7 and $\mathrm{pH}$ values of 8-11, respectively (Bates \& Bower, 1956; Gomori, 1955). Degradation of DNA [using DNA agar (Difco) supplemented with $0.01 \%$ toluidine blue (Merck)], degradation of casein, chitin and starch (Atlas, 1993), and degradation of cellulose and xylan (Ten et al., 2004) were investigated. Antibiotic susceptibility tests were done in duplicate using filter-paper disks containing the following: ampicillin $(20 \mu \mathrm{g})$, chloramphenicol $(100 \mu \mathrm{g})$, erythromycin $(25 \mu \mathrm{g})$, gentamicin $(30 \mu \mathrm{g})$, kanamycin $(30 \mu \mathrm{g})$, lincomycin $(15 \mu \mathrm{g})$, neomycin $(30 \mu \mathrm{g})$, novobiocin $(5 \mu \mathrm{g})$, oleandomycin $(15 \mu \mathrm{g})$, penicillin G (20 IU), streptomycin $(50 \mu \mathrm{g})$ and tetracycline $(30 \mu \mathrm{g})$ (Sigma). Carbon source utilization tests, acid production tests and additional physiological tests were performed using API 20NE, API ID $32 \mathrm{GN}$, API 50CH and API ZYM galleries according to the instructions of the manufacturer (bioMérieux).

Fatty acid methyl esters were prepared from bacteria grown in $\mathrm{R} 2 \mathrm{~A}$ medium for 2 days at $30{ }^{\circ} \mathrm{C}$ and saponified,

Table 1. Phenotypic characteristics that distinguish strains $2 \mathrm{C} 1-\mathrm{b}^{\top}$ and $2 \mathrm{C} 1-21$ from other Variovorax species

Strains: 1, 2C1-b ${ }^{\mathrm{T}}$; 2, 2C1-21; 3, V. boronicumulans KCTC $22010^{\mathrm{T}}$; 4, V. dokdonensis $\mathrm{KCTC} 12544^{\mathrm{T}}$; 5, V. ginsengisoli KCTC $12583^{\mathrm{T}}$; 6, V. paradoxus ATCC $17713^{\mathrm{T}} ; 7$, V. soli KACC $11579^{\mathrm{T}}$. All data are from this study unless indicated. All strains were positive for catalase, oxidase, esterase lipase (C8) and leucine arylamidase but negative for nitrite reduction, indole production, glucose fermentation, arginine dihydrolase, gelatin hydrolysis, $N$-acetyl- $\beta$-glucosaminidase, $\alpha$-chymotrypsin, cystine arylamidase, $\alpha$-fucosidase, $\alpha$-galactosidase, $\beta$-galactosidase, $\beta$-glucosidase, $\beta$-glucuronidase, lipase (C14), $\alpha$-mannosidase and trypsin. All strains assimilated L-arabinose, histidine, 4-hydroxybenzoate, 3-hydroxybutyrate, 2 -ketogluconate and suberate. None of the strains assimilated $\mathrm{N}$-acetylglucosamine, caprate, maltose, rhamnose, inositol, sucrose, glycogen, L-serine, melibiose or salicin. All strains were grown on R2A for 2 days. +, Positive; -, negative; w, weakly positive.

\begin{tabular}{|c|c|c|c|c|c|c|c|}
\hline Characteristic & 1 & 2 & 3 & 4 & 5 & 6 & 7 \\
\hline Nitrate reduction & + & + & - & - & + & + & + \\
\hline Urease & - & - & - & + & - & - & - \\
\hline Aesculin hydrolysis & + & + & - & - & - & - & - \\
\hline \multicolumn{8}{|l|}{ Assimilation of: } \\
\hline Acetate & + & + & $\mathrm{W}$ & + & + & - & + \\
\hline Adipate & + & + & - & + & - & + & + \\
\hline L-Alanine & $\mathrm{w}$ & $\mathrm{w}$ & $\mathrm{W}$ & + & + & - & + \\
\hline L-Fucose & - & - & - & - & - & + & - \\
\hline Glucose & - & - & + & + & - & + & - \\
\hline Gluconate & + & + & - & + & - & + & + \\
\hline 3-Hydroxybenzoate & + & + & + & + & - & + & + \\
\hline Itaconate & + & + & - & - & - & - & - \\
\hline 5-Ketogluconate & - & - & + & - & - & + & - \\
\hline DL-Lactate & + & + & $\mathrm{W}$ & + & + & - & + \\
\hline Malate & + & + & + & + & - & + & + \\
\hline Malonate & + & + & - & - & + & - & - \\
\hline D-Mannitol & - & - & + & - & + & + & + \\
\hline D-Mannose & - & - & - & - & + & + & - \\
\hline Phenylacetate & - & - & - & - & + & + & + \\
\hline L-Proline & - & - & + & + & + & + & + \\
\hline Propionate & + & + & + & + & + & - & + \\
\hline D-Ribose & - & - & + & - & - & + & - \\
\hline D-Sorbitol & - & - & + & - & - & + & - \\
\hline Valerate & + & + & + & + & + & - & + \\
\hline \multicolumn{8}{|l|}{ Enzyme activities: } \\
\hline Acid phosphatase & - & - & $\mathrm{W}$ & + & + & - & + \\
\hline Alkaline phosphatase & - & - & + & + & $\mathrm{w}$ & + & + \\
\hline Esterase $(\mathrm{C} 4)$ & + & + & - & $\mathrm{w}$ & + & + & + \\
\hline$\alpha$-Glucosidase & - & - & - & + & + & + & - \\
\hline Naphthol-AS-BI-phosphohydrolase & - & - & - & - & - & - & + \\
\hline Valine arylamidase & - & - & - & - & w & + & - \\
\hline DNA G $+C$ content $(\mathrm{mol} \%)$ & 65.5 & 65.2 & $71.2^{a_{\star}}$ & $66.0^{b}$ & $66.0^{c}$ & $67.0^{d}$ & $67.1^{e}$ \\
\hline
\end{tabular}

${ }^{\star}$ Data from: a, Miwa et al. (2008); b, Yoon et al. (2006); c, Im et al. (2010); d, Willems et al. (1991); e, Kim et al. (2006). 
methylated, extracted and analysed (Sasser, 1990) according to the protocol of the Sherlock Microbial Identification System (MIDI). Extracts were analysed by GC (Hewlett Packard 6890) and identified by comparing the fatty acid profiles to the TSBA 3.9 database provided with the Sherlock software 2.95. Isoprenoid quinones were analysed by HPLC as described by Groth et al. (1996).

Extraction of genomic DNA, PCR-mediated amplification of the 16S rRNA genes and sequencing of purified PCR products were carried out according to Rainey et al. (1996). $16 \mathrm{~S}$ rRNA gene sequences were aligned with published sequences retrieved from GenBank/EMBL using CLUSTAL_X (Thompson et al., 1997) and edited using BIOEDIT (Hall, 1999). The phylogenetic tree was reconstructed on the basis of the neighbour-joining method (Saitou \& Nei, 1987); distances were estimated using the Kimura two-parameter model (Kimura, 1983) with MEGA version 3.1 (Kumar et al., 2004). The resultant tree topology was evaluated by bootstrap analysis (Felsenstein, 1985) based on 1000 resampled dataset. DNA G $+\mathrm{C}$ content was determined by HPLC after hydrolysis as described by Tamaoka \& Komagata (1984) and non-methylated $\lambda$ DNA (Sigma) was used as a standard. DNA-DNA hybridization to determine genomic relatedness was performed fluorometrically by the method of Ezaki et al. (1989) using DNA probes labelled with photobiotin (Sigma) and microdilution wells (Greiner Bioone; 96-well microplate).

Strains $2 \mathrm{C} 1-\mathrm{b}^{\mathrm{T}}$ and $2 \mathrm{C} 1-21$ formed visible colonies on $\mathrm{R} 2 \mathrm{~A}$ agar incubated at $30{ }^{\circ} \mathrm{C}$ within $48 \mathrm{~h}$. Growth occurred at temperatures ranging from 8 to $37^{\circ} \mathrm{C}$, but no growth was observed at $4{ }^{\circ} \mathrm{C}$ or at $42{ }^{\circ} \mathrm{C}$. Growth occurred at pH 6-9, but no growth was observed at pH 5 or 10. Cells were Gram-negative, motile and oval- or rod-shaped. Colonies on R2A were circular, slightly convex, smooth, glistening and yellow in colour. Detailed physiological and biochemical characteristics are summarized in Table 1 and in the species description.

The almost-complete 16S rRNA gene sequences (approx. $1450 \mathrm{nt})$ of strains $2 \mathrm{C} 1-\mathrm{b}^{\mathrm{T}}$ and $2 \mathrm{C} 1-21$ were determined and compared with those of representative species within the genus Variovorax. Strains 2C1-b ${ }^{\mathrm{T}}$ and $2 \mathrm{C} 1-21$ shared $100 \% 16 \mathrm{~S}$ rRNA gene sequence similarity. The novel strains showed highest levels of 16S rRNA gene sequence similarity to $V$. boronicumulans KCTC $22010^{\mathrm{T}}$, V. dokdonensis KCTC $12544^{\mathrm{T}}, V$. ginsengisoli KCTC $12583^{\mathrm{T}}, V$. paradoxus ATCC $17713^{\mathrm{T}}$ and V. soli KACC $11579^{\mathrm{T}}$ with similarities of $97.3,97.6,97.9,97.4$ and $98.8 \%$, respectively. In the phylogenetic tree, strains $2 \mathrm{C} 1-\mathrm{b}^{\mathrm{T}}$ and $2 \mathrm{C} 1-21$ occupied a distinct position and formed a relatively stable branch with members of the genus Variovorax (Fig. 1). DNA-DNA hybridization experiments were performed to confirm the taxonomic status of the novel strains. Strains $2 \mathrm{C}^{-}-\mathrm{b}^{\mathrm{T}}$ and 2C1-21 shared 90\% DNA-DNA relatedness, and showed levels of relatedness of $19-41 \%$ with $V$. boronicumulans KCTC $22010^{\mathrm{T}}, V$. dokdonensis KCTC $12544^{\mathrm{T}}$, V. ginsengisoli KCTC $12583^{\mathrm{T}}$, V. paradoxus ATCC $17713^{\mathrm{T}}$ and V. soli KACC $11579^{\mathrm{T}}$. These values are well below the $70 \%$ cut-off point recommended for the delineation of genomic species (Wayne et al., 1987).

The genomic DNA G $+\mathrm{C}$ content of the novel strains was 65.2-65.5 mol\%. The major fatty acids were $\mathrm{C}_{16: 0}$, summed feature $4\left(\mathrm{C}_{16: 1} \omega 7 c\right.$ and/or iso- $\left.\mathrm{C}_{15: 0} 2-\mathrm{OH}\right), \mathrm{C}_{17: 0}$ cyclo and summed feature $7\left(\mathrm{C}_{18: 1} \omega 7 c\right.$ and/or $\omega 9 t$ and/or $\left.\omega 12 t\right)$. This fatty acid profile was similar to those of the five recognized Variovorax species, although there were differences in the proportions of some fatty acids (Table 2 ). Chemotaxonomic data together with phylogenetic analysis support the affiliation of strains $2 \mathrm{C} 1-\mathrm{b}^{\mathrm{T}}$ and $2 \mathrm{C} 1-21$ to the genus Variovorax.

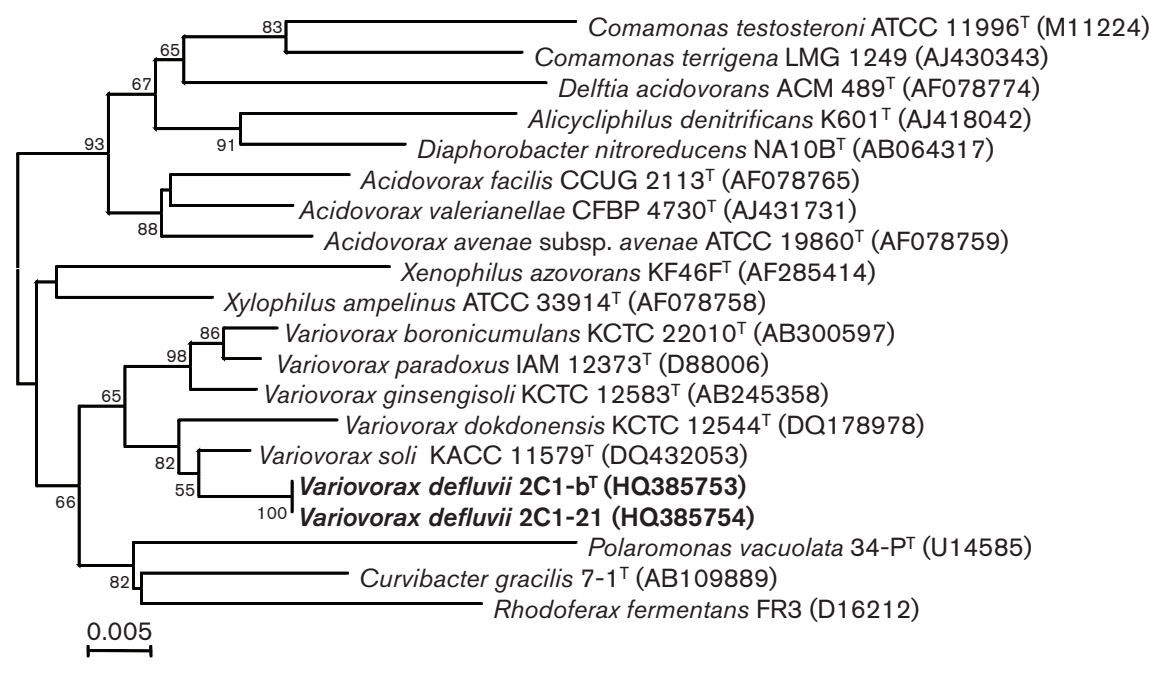

Fig. 1. Phylogenetic tree based on $16 \mathrm{~S}$ rRNA gene sequences using the neighbour-joining method (Saitou \& Nei, 1987) showing the positions of strains $2 \mathrm{C} 1-\mathrm{b}^{\top}$ and $2 \mathrm{C} 1-21$ and related taxa. Numbers at branch points refer to bootstrap percentage (1000 resamplings; only values above $50 \%$ shown). Bar, 0.5 substitutions per 100 nt positions. 
Table 2. Cellular fatty acid compositions (\%) of strains $2 \mathrm{C} 1-\mathrm{b}^{\top}$ and 2C1-21 and the type strains of related Variovorax species

Strains: 1, 2C1-b ${ }^{\mathrm{T}} ; 2$, 2C1-21; 3, V. boronicumulans KCTC $22010^{\mathrm{T}} ; 4$, V. dokdonensis KCTC $12544^{\mathrm{T}} ; 5, V$. ginsengisoli KCTC $12583^{\mathrm{T}} ; 6, V$. paradoxus ATCC $17713^{\mathrm{T}} ; 7$, V. soli KACC $11579^{\mathrm{T}}$. All data are from this study. Cells of all strains were harvested after growth on R2A medium at $30{ }^{\circ} \mathrm{C}$ for 2 days. -, Not detected.

\begin{tabular}{|lccccccc|}
\hline Fatty acid & $\mathbf{1}$ & $\mathbf{2}$ & $\mathbf{3}$ & $\mathbf{4}$ & $\mathbf{5}$ & $\mathbf{6}$ & $\mathbf{7}$ \\
\hline $\mathrm{C}_{10: 0}$ & - & - & 0.5 & - & 0.8 & - & 0.6 \\
$\mathrm{C}_{10: 0} 3-\mathrm{OH}$ & 2.1 & 1.9 & 3.2 & 2.9 & 2.7 & 3.5 & 5.7 \\
$\mathrm{C}_{12: 0}$ & 3.3 & 3.2 & 3.1 & 5.7 & 3.3 & 2.7 & 2.8 \\
$\mathrm{C}_{12: 0} 3-\mathrm{OH}$ & - & - & - & 2.4 & - & - & - \\
$\mathrm{C}_{14: 0}$ & 2.0 & 1.9 & 1.6 & 1.4 & 4.2 & 1.2 & 1.2 \\
$\mathrm{C}_{14: 0} 2-\mathrm{OH}$ & 2.2 & 1.9 & 1.2 & - & - & 3.3 & - \\
$\mathrm{C}_{15: 0}$ & 1.1 & 1.4 & - & 1.2 & 2.1 & 5.9 & 0.7 \\
$\mathrm{C}_{15: 1} \omega 6 c$ & 0.6 & 0.6 & - & 0.8 & - & 1.8 & - \\
$\mathrm{C}_{16: 0}$ & 36.5 & 35.7 & 33.7 & 26.8 & 37.5 & 27.2 & 31.6 \\
$\mathrm{C}_{16: 1} \omega 5 c$ & - & - & - & - & - & 1.9 & - \\
$\mathrm{C}_{16: 1} 2-\mathrm{OH}$ & - & - & - & - & - & 0.8 & - \\
$\mathrm{C}_{17: 0}$ & 0.8 & 0.9 & 1.2 & 1.7 & - & 1.6 & 1.4 \\
$\mathrm{C}_{17: 0}$ cyclo & 11.8 & 15.5 & 21.6 & 17.3 & 22.5 & 16.5 & 18.3 \\
$\mathrm{C}_{18: 0}$ & 1.1 & 0.8 & - & - & - & - & - \\
Summed feature $4^{*}$ & 27.8 & 24.9 & 20.7 & 23.3 & 16.3 & 21.7 & 28.8 \\
Summed feature $7 \dagger$ & 10.8 & 11.0 & 12.8 & 15.7 & 8.6 & 11.6 & 8.4 \\
& & & & & & & \\
\hline
\end{tabular}

${ }^{\star}$ Contains $\mathrm{C}_{16: 1} \omega 7 c$ and/or iso- $\mathrm{C}_{15: 0} 2-\mathrm{OH}$.

†Contains $\mathrm{C}_{18: 1} \omega 7 c$ and/or $\omega 9 t$ and/or $\omega 12 t$.

The mean DNA-DNA relatedness value between strains $2 \mathrm{C} 1-\mathrm{b}^{\mathrm{T}}$ and $2 \mathrm{C} 1-21$ and the type strains of members of the genus Variovorax was 19-41\% when their DNAs were used individually as labelled DNA probes for cross-hybridization. This value indicated that they represent different genomic species (Wayne et al., 1987). Therefore, on the basis of the data presented, strains $2 \mathrm{C} 1-\mathrm{b}^{\mathrm{T}}$ and $2 \mathrm{C} 1-21$ represent a novel species of the genus Variovorax, for which the name Variovorax defluvii sp. nov. is proposed.

\section{Description of Variovorax defluvii sp. nov.}

Variovorax defluvii (de.flu'vi.i. L. gen. n. defluvii of sewage).

Cells are Gram-negative, non-spore-forming, motile, ovalor rod-shaped, $0.4-0.5 \mu \mathrm{m}$ in diameter and $0.8-2.0 \mu \mathrm{m}$ in length. Colonies on R2A agar are circular, slightly convex, smooth, glistening and yellow in colour. Good growth is observed on R2A agar at $28-32{ }^{\circ} \mathrm{C}$. Growth occurs at 8 $37^{\circ} \mathrm{C}$, but not at 4 or $42{ }^{\circ} \mathrm{C}$. Optimal pH for growth is 7.0 ; growth occurs at $\mathrm{pH} 6.0-9.0$, but not at $\mathrm{pH} 5.0$ or 10.0. Growth occurs in the presence of 1 and $2 \% \mathrm{NaCl}$, but not in $>3 \% \mathrm{NaCl}$. Oxidase and catalase are positive. Hydrolyses casein but does not hydrolyse chitin, DNA, starch, cellulose or xylan. Positive for nitrate reduction and aesculin hydrolysis but negative for nitrite reduction, indole production, glucose fermentation, arginine dihydrolase, urease and gelatin hydrolysis (API 20NE test strip).
Assimilates acetate, adipate, L-alanine (weakly), L-arabinose, gluconate, histidine, 4-hydroxybenzoate, 3-hydroxybenzoate, 3-hydroxybutyrate, itaconate, 2-ketogluconate, DL-lactate, malate, malonate, propionate, suberate and valerate. Does not assimilate $\mathrm{N}$-acetylglucosamine, caprate, citrate, L-fucose, D-glucose, glycogen, inositol, 5-ketogluconate, maltose, D-mannitol, D-mannose, melibiose, phenylacetate, L-proline, rhamnose, D-ribose, salicin, L-serine, D-sorbitol or sucrose (API 20NE and API ID 32GN test strips). Positive for (API ZYM test strip) esterase (C4), esterase lipase (C8) and leucine arylamidase but negative for $N$-acetyl- $\beta$-glucosaminidase, acid phosphatase, alkaline phosphatase, $\alpha$-chymotrypsin, cystine arylamidase, $\alpha$-fucosidase, $\alpha$-galactosidase, $\beta$-galactosidase, $\alpha$-glucosidase, $\beta$ glucosidase, $\beta$-glucuronidase, lipase (C14), $\alpha$-mannosidase, naphthol-AS-BI-phosphohydrolase, trypsin and valine arylamidase. Acid is produced from aesculin, L-arabinose, fructose (weakly) and D-fucose, but not from $\mathrm{N}$-acetylglucosamine, adonitol, amygdalin, D-arabinose, D-arabitol, L-arabitol, arbutin, cellobiose, dulcitol, erythritol, L-fucose, galactose, gentiobiose, gluconate, glucose, glycerol, glycogen, inositol, inulin, 2-ketogluconate, 5-ketogluconate, lactose, D-lyxose, maltose, mannitol, mannose, melezitose, melibiose, methyl $\alpha$-D-glucoside, methyl $\alpha$-D-mannoside, methyl $\beta$-D-xylose, raffinose, rhamnose, ribose, salicin, sorbitol, sorbose, sucrose, starch, D-tagatose, trehalose, turanose, xylitol, D-xylose or L-xylose. Susceptible to ampicillin $(20 \mu \mathrm{g})$, lincomycin $(15 \mu \mathrm{g})$, neomycin $(30 \mu \mathrm{g})$ and penicillin G (20 IU) but resistant to chloramphenicol $(100 \mu \mathrm{g})$, erythromycin $(25 \mu \mathrm{g})$, gentamicin $(30 \mu \mathrm{g})$, kanamycin $(30 \mu \mathrm{g})$, novobiocin $(5 \mu \mathrm{g})$, oleandomycin $(15 \mu \mathrm{g})$, streptomycin $(50 \mu \mathrm{g})$ and tetracycline $(30 \mu \mathrm{g})$. The predominant ubiquinone is $\mathrm{Q}-8$. The major fatty acids are $\mathrm{C}_{16: 0}$, summed feature $4\left(\mathrm{C}_{16: 1} \omega 7 c\right.$ and/or iso- $\left.\mathrm{C}_{15: 0} 2-\mathrm{OH}\right), \mathrm{C}_{17: 0}$ cyclo and summed feature $7\left(\mathrm{C}_{18: 1} \omega 7 c\right.$ and/or $\omega 9 t$ and/or $\left.\omega 12 t\right)$. The $\mathrm{G}+\mathrm{C}$ content of the genomic DNA is $65.2-65.5 \mathrm{~mol} \%$.

The type strain, $2 \mathrm{C} 1-\mathrm{b}^{\mathrm{T}}\left(=\mathrm{KCTC} 12768^{\mathrm{T}}=\mathrm{JCM} 17804^{\mathrm{T}}\right)$, was isolated from sewage flowing into River Geumho in Korea. The genomic DNA G + C content of the type strain is $65.5 \mathrm{~mol} \%$.

\section{Acknowledgements}

This research was supported by grants from the Advanced Biomass R\&D Center, a Global Frontier Program funded by the Ministry of Education, Science \& Technology and the CAER (Center for Aquatic Ecosystem Restoration) of Eco-STAR project from the Ministry of Environment.

\section{References}

Apajalahti, J. H. \& Salkinoja-Salonen, M. S. (1987). Dechlorination and para-hydroxylation of polychlorinated phenols by Rhodococcus chlorophenolicus. J Bacteriol 169, 675-681.

Atlas, R. M. (1993). Handbook of Microbiological Media. Edited by L. C. Parks. Boca Raton, FL: CRC Press.

Bates, R. G. \& Bower, V. E. (1956). Alkaline solutions for $\mathrm{pH}$ control. Anal Chem 28, 1322-1324. 
Ezaki, T., Hashimoto, Y. \& Yabuuchi, E. (1989). Fluorometric deoxyribonucleic acid-deoxyribonucleic acid hybridization in microdilution wells as an alternative to membrane filter hybridization in which radioisotopes are used to determine genetic relatedness among bacterial strains. Int J Syst Bacteriol 39, 224-229.

Felsenstein, J. (1985). Confidence limits on phylogenies: an approach using the bootstrap. Evolution 39, 783-791.

Gerhardt, P., Murray, R. G. E., Wood, W. A. \& Krieg, N. R. (editors) (1994). Methods for General and Molecular Bacteriology. Washington, DC: American Society for Microbiology.

Gomori, G. (1955). Preparation of buffers for use in enzyme studies. Methods Enzymol 1, 138-146.

Groth, I., Schumann, P., Weiss, N., Martin, K. \& Rainey, F. A. (1996). Agrococcus jenensis gen. nov., sp. nov., a new genus of actinomycetes with diaminobutyric acid in the cell wall. Int J Syst Bacteriol 46, 234-239.

Häggblom, M. M. (1990). Mechanisms of bacterial degradation and transformation of chlorinated monoaromatic compounds. J Basic Microbiol 30, 115-141.

Häggblom, M. M. (1992). Microbial breakdown of halogenated aromatic pesticides and related compounds. FEMS Microbiol Rev 9, 29-71.

Hall, T. A. (1999). BioEdit: a user-friendly biological sequence alignment editor and analysis program for Windows 95/98/NT. Nucleic Acids Symp Ser 41, 95-98.

Im, W.-T., Liu, Q.-M., Lee, K.-J., Kim, S.-Y., Lee, S.-T. \& Yi, T. H. (2010), Variovorax ginsengisoli sp. nov., a denitrifying bacterium isolated from soil of a ginseng field. Int J Syst Evol Microbiol 60, 1565-1569.

Kim, B.-Y., Weon, H.-Y., Yoo, S.-H., Lee, S.-Y., Kwon, S.-W., Go, S.-J. \& Stackebrandt, E. (2006). Variovorax soli sp. nov., isolated from greenhouse soil. Int J Syst Evol Microbiol 56, 2899-2901.

Kimura, M. (1983). The Neutral Theory of Molecular Evolution. Cambridge: Cambridge University Press.

Kumar, S., Tamura, K. \& Nei, M. (2004). MEGA3: integrated software for molecular evolutionary genetics analysis and sequence alignment. Brief Bioinform 5, 150-163.

Li, D.-Y., Eberspächer, J., Wagner, B., Kuntzer, J. \& Lingens, F. (1991). Degradation of 2,4,6-trichlorophenol by Azotobacter sp. strain GP1. Appl Environ Microbiol 57, 1920-1928.

Martin-Le Garrec, G., Artaud, I. \& Capeillère-Blandin, C. (2001). Purification and catalytic properties of the chlorophenol 4-monooxygenase from Burkholderia cepacia strain AC1100. Biochim Biophys Acta 1547, 288-301.

Miwa, H., Ahmed, I., Yoon, J., Yokota, A. \& Fujiwara, T. (2008). Variovorax boronicumulans sp. nov., a boron-accumulating bacterium isolated from soil. Int J Syst Evol Microbiol 58, 286-289.

Rainey, F. A., Ward-Rainey, N., Kroppenstedt, R. M. \& Stackebrandt, E. (1996). The genus Nocardiopsis represents a phylogenetically coherent taxon and a distinct actinomycete lineage: proposal of Nocardiopsaceae fam. nov. Int J Syst Bacteriol 46, 1088-1092.

Saitou, N. \& Nei, M. (1987). The neighbor-joining method: a new method for reconstructing phylogenetic trees. Mol Biol Evol 4, 406425.

Sasser, M. (1990). Identification of bacteria by gas chromatography of cellular fatty acids, MIDI Technical Note 101. Newark, DE: MIDI Inc.

Tamaoka, J. \& Komagata, K. (1984). Determination of DNA base composition by reversed-phase high-performance liquid chromatography. FEMS Microbiol Lett 25, 125-128.

Tarrand, J. J. \& Gröschel, D. H. M. (1982). Rapid, modified oxidase test for oxidase-variable bacterial isolates. J Clin Microbiol 16, 772774 .

Ten, L. N., Im, W.-T., Kim, M.-K., Kang, M. S. \& Lee, S.-T. (2004). Development of a plate technique for screening of polysaccharidedegrading microorganisms by using a mixture of insoluble chromogenic substrates. J Microbiol Methods 56, 375-382.

Thompson, J. D., Gibson, T. J., Plewniak, F., Jeanmougin, F. \& Higgins, D. G. (1997). The CLUSTAL_X windows interface: flexible strategies for multiple sequence alignment aided by quality analysis tools. Nucleic Acids Res 25, 4876-4882.

Wayne, L. G., Brenner, D. J., Colwell, R. R., Grimont, P. A. D., Kandler, O., Krichevsky, M. I., Moore, L. H., Moore, W. E. C., Murray, R. G. E. \& other authors (1987). International Committee on Systematic Bacteriology. Report of the ad hoc committee on reconciliation of approaches to bacterial systematics. Int J Syst Bacteriol 37, 463-464.

Willems, A., De Ley, J., Gillis, M. \& Kersters, K. (1991). Comamonadaceae, a new family encompassing the Acidovorans rRNA complex, including Variovorax paradoxus gen. nov., comb. nov., for Alcaligenes paradoxus (Davis 1969). Int J Syst Bacteriol 41, 445-450.

Yoon, J.-H., Kang, S.-J. \& Oh, T.-K. (2006). Variovorax dokdonensis sp. nov., isolated from soil. Int J Syst Evol Microbiol 56, 811-814. 